May Elsayyad

Shima'a Hanafy

\title{
Voting Islamist or Voting Secular? An Empirical Analysis of Voting Outcomes in "Arab Spring" Egypt
}

\section{Max Planck Institute for Tax Law and Public Finance \\ Working Paper 2013 - 01}

February 2013

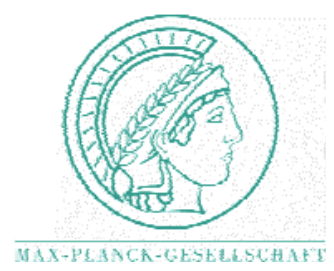

Max Planck Institute for

Tax Law and Public Finance

Department of Business and Tax Law

Department of Public Economics

http://www.tax.mpg.de 
Working papers of the Max Planck Institute for Tax Law and Public Finance Research Paper Series serve to disseminate the research results of work in progress prior to publication to encourage the exchange of ideas and academic debate. Inclusion of a paper in the Research Paper Series does not constitute publication and should not limit publication in any other venue. The preprints published by the Max Planck Institute for Tax Law and Public Finance represent the views of the respective author(s) and not of the Institute as a whole. Copyright remains with the author(s).

Max Planck Institute for Tax Law and Public Finance

Marstallplatz 1

D-80539 Munich

Tel: $\quad+498924246-0$

Fax: $\quad+498924246-501$

E-mail: ssrn@tax.mpg.de

http://www.tax.mpg.de 


\title{
Voting Islamist or Voting secular? An empirical analysis of Voting Outcomes in “Arab Spring” Egypt
}

\author{
By May Elsayyad* and Shima'a Hanafy*
}

This version: February 2013

\begin{abstract}
This paper empirically studies the voting outcomes of Egypt's first parliamentary elections after the Arab Spring. In light of the strong Islamist success in the polls, we explore the main determinants of Islamist vs. secular voting. We identify three dimensions that affect voting outcomes at the constituency level: the socio-economic profile, the economic structure and the electoral institutional framework. Our results show that education is negatively associated with Islamist voting. Interestingly, we find significant evidence which suggests that higher poverty levels are associated with a lower vote share for Islamist parties. Later voting stages in the sequential voting setup do not exhibit a bandwagon effect.
\end{abstract}

JEL Codes: D72, D78, O53, P26, Z12, Z13

Keywords: $\quad$ Voting Outcomes, Arab Spring, Political Islam, Sequential Voting

\footnotetext{
* Max Planck Institute for Tax Law and Public Finance, Munich and MGSE, Munich.

* Philipps-University Marburg, Faculty of Economics and Business Administration, Am Plan 2, D-35032

Marburg, Germany, Phone: +49-6421-2823200, Fax: +49-6421-282 8912,

Email: hanafy@wiwi.uni-marburg.de
}

The authors thank Boban Aleksandrovic, Moamen Gouda, Bernd Hayo, Kai Konrad, Tim Krieger, Florian Neumeier, Salmai Qari, Christian Traxler, Mathias Uhl, Susanne Väth, Stefan Voigt and participants of the "Constitutional Choice in the Middle East" conference in Hamburg (July 2012) and research seminars in Marburg and Munich for helpful comments and suggestions. All remaining shortcomings are our own. 


\section{Introduction}

The Arab Spring has heralded the beginning of a new wave of democratisation in the Middle East. ${ }^{1}$ In Tunisia and Egypt, the ousting of Ben Ali and Mubarak has placed both countries on a transitional path to democracy. While Tunisia has opted for a direct election of a constitutional committee, Egypt has chosen its transition to democracy through parliamentary elections. In this paper, we will focus on the case of Egypt for the following reasons: These Egyptian elections, next to being the first relatively free and fair elections after the ousting of Mubarak, have had the added importance that the elected parliament's main competence is the appointment of a committee for the drafting of a new constitution. As such, they can be seen as a crucial determinant of the direction of the transition. It is important to note that Egypt's first democratic election has been documented as a resounding success for the Islamist political groups, as Islamist parties attracted more than 70 per cent of the vote.

An additional important aspect of these elections is the fact that they are some of the first relatively free and fair elections in the entire Arab region and, thus, can allow an identification of the will of the people. Besides, being one of the Arab world's most populous countries, Egypt's stature as an influential actor in the Arab world is such that an Islamist victory - at the polls or in the streets - can have a significant impact on the region. Furthermore, Egypt's cultural and political centrality in the Arab world and its strategic role in preserving the current regional balance of power further raise the importance of understanding the main mechanism driving recent Egyptian voting trends (see Wickham, 2002).

This paper empirically analyses the voting outcomes of the first parliamentary elections of post-revolution Egypt at the constituency level, along one particular dimension, namely the secular vs. Islamist spectrum. The transitional period has seen an increase in new political party formations from all sides of the political spectrum. With the central theme of the elections focusing on the drafting of the new constitution, both old and new parties have positioned themselves along the secular-Islamist dimension, all trying to define Egypt's future political identity.

\footnotetext{
${ }^{1}$ To date, rulers have been forced from power in Tunisia, Egypt, Libya and Yemen; Syria is engaged in a civil war; major protests have broken out in Algeria, Bahrain, Iraq, Jordan, Kuwait, Morocco and Oman; and minor protests have occurred in Lebanon, Mauritania, Saudi Arabia, Sudan and Western Sahara.
} 
Using the voting outcomes of the country's 2011/2012 parliamentary elections at the constituency level, our cross-sectional analysis identifies three dimensions which can affect voting outcomes: the socio-economic background of a constituency, the economic and employment structure of a constituency and the institutional framework of the voting procedure. Merging the voting data with Egypt's most recent Population and Housing Census data, our results show that the socio-economic structure of a constituency plays the strongest role when it comes to explaining voting outcomes.

Our analysis shows that the level of education seems to be a strong and robust predictor of secular and Islamist voting levels. A higher share of university graduates in a constituency is significantly correlated with a higher share of secular voting and lower share of Islamist voting. Furthermore, illiteracy shows a significant positive correlation with the share of voting for Islamist parties. A particularly important result of our analysis pertains to the effect of poverty on voting outcomes. Interestingly, when controlling for education levels, higher poverty levels do not correspond to higher shares of voting for Islamist parties. In fact, a higher level of poverty is associated with a lower support for Islamist parties. This is particularly surprising given the strong social outreach character of Islamist groups.

Our analysis further confirms the notion that the sequential voting framework and the timing of elections affect voting outcomes. Specifically, we exploit the sequential nature of the vote to determine how later stage constituencies have reacted to the resounding success of Islamist parties in the early stages of the vote. We find no evidence for a bandwagon effect. In fact, voters showed significantly less support to Islamist parties in the last stage of the vote.

This paper is related to three main strands of literature: First, the literature on the relationship between Islam and democracy; second, the literature on economic voting in economies of transition with a novel application in the context of the Arab Spring; and third, the empirical literature on the impact of sequential voting.

Our paper contributes to the empirical literature on Islam and democracy. This particular literature analyses Muslim attitudes towards democracy. For example, Potrafke (2011) and Rowley and Smith (2009) analyse the effect that the share of Muslims in a total population has on democracy levels. Our approach contributes to this literature by attempting to identify 
the underlying mechanism which pushes constituencies towards encouraging political Islam or supporting more secular political groups. ${ }^{2}$

Given the unique timing of our data - capturing a nation in a transition brought about by the Arab Spring - our paper also contributes to the analysis of empirical voting outcomes in transition economies which have been most notably studied in Fidrmuc (2000). He analyses the relationship between economics and politics across eight parliamentary elections in the Czech Republic, Hungary, Poland and Slovakia and mainly shows that, in contrast to the responsibility hypothesis, voters in transition economies are mainly found to be forward looking rather than retrospective. In our analysis, we use the insights of Swank and Eisinga (1999) on multi-party systems and economic voting outcomes to help us identify the main determinants of voting outcomes in the Egyptian context. ${ }^{3}$

Next to identifying the main determinants which influences Islamist versus secular voting outcomes, the sequential nature of voting in Egypt's most recent parliamentary elections allows us to further analyse the impact of timing on these elections. There exists extensive theoretical and empirical literature on sequential voting. ${ }^{4}$ The fact that interim results are announced in the Egyptian elections is likely to have an influence on later voting stages. By controlling for the voting stages, our empirical analysis investigates the direction to which the sequential voting procedure has influenced the voting outcome.

The paper is structured as follows. Section 2 presents the institutional setup of the underlying elections and identifies the main institutional players. Section 3 introduces the data and derives the theoretical hypotheses upon which we base the empirical strategy and estimations. Section 4 presents the empirical approach and regression results. Section 5 presents a series of robustness checks while Section 6 concludes.

\footnotetext{
${ }^{2}$ For example, studies on voting in Turkey have noted that unemployed males have a higher likelihood of voting for Islamists than other voter segments (e.g. Akarca and Tansel, 2006; Genc et al., 2005; and Baslevent et al., 2005).

${ }^{3}$ This strand of the literature has been more or less successful in testing the economic responsibility hypotheses. See Lewis-Beck and Stegmaier (2000) for a survey.

${ }^{4}$ In the theoretical strand of the literature, there are varying results with regard to the impact of timing on voting outcomes. Dekel and Piccione (1997), for example, show that the symmetric simultaneous voting equilibria are also equilibria in any sequential voting structure, while Battaglini (2005) shows that when voters can abstain, the set of equilibria in the two mechanisms are actually disjoint. The extensive empirical literature has mainly concentrated on testing the implications of the theoretical frameworks in the laboratory. For a survey, see Palfrey (2009).
} 


\section{Institutional Setup}

In this section, we introduce the electoral institutional setup for the 2011/12 elections of the People's Assembly (the lower house of parliament) in Egypt. ${ }^{5}$ According to the Carter Center's preliminary report, the People's Assembly elections are an accurate expression of the will of the people. ${ }^{6}$ These elections have been the first relatively free and fair elections in Egypt's recent history and a major step in the country's transitional path after the Jan 25 Revolution in 2011. As to the voting participation, the reported overall turnout was $54 \%$, a marked increase for Egypt. About 50 million of Egypt's ca. 85 million citizens were eligible to vote.

The Egyptian transitional phase has been mainly shaped by the Supreme Council of the Armed Forces (SCAF) and the March 19, 2011 constitutional referendum. The constitutional referendum gave the newly elected parliament the power to appoint a commission for the drafting of a new constitution and was approved by $77 \%$ of the vote. ${ }^{7}$ In consequence, given this mandate, these elections have a longer term reach with regard to defining Egypt's political framework for years to come. After the approval of the referendum, electoral and party formation laws were altered by the SCAF. In the following, we introduce the electoral framework and highlight the most important aspects related to our analysis of the voting outcomes.

\subsection{Electoral Framework}

Before the Egyptian revolution, parliamentary elections used the French style single winner voting system, a women's quota and a 50\% quota for farmers and labourers in the parliament. The new electoral framework was altered along several dimensions. ${ }^{8}$ Most significant has been the change in the electoral system such that two thirds out of the 498 People's Assembly seats would be elected from parties or party coalition lists using the proportional representation method with a 0.5 per cent threshold in 46 constituencies. The remaining third of the People's Assembly seats would continue to be elected via the French majority voting system for 83 single district constituencies. Note that for the proportional vote seats, constituencies were weighted by their population size. The number of seats allotted for each

\footnotetext{
${ }^{5}$ Egypt has a bicameral Parliament consisting of the Advisory Council and the People's Assembly.

${ }^{6}$ See the Carter Center election witnessing mission preliminary report on Egypt's 2011/2012 parliamentary elections http://www.cartercenter.org. Accessed on 29.07.2012.

7 See Article 189 of the referendum.

${ }^{8}$ Information on the electoral framework and results are taken from the official website of the Egyptian parliamentary elections 2011/2012 http://www.elections2011.eg/. Accessed on 19.04.2012.
} 
constituency was between 4 and 12. The new electoral framework continued the Nasserist tradition of a $50 \%$ quote for farmers and labourers. Instead of the women's quota, however, party lists only had to include at least one woman on each list.

In 2000, the Supreme Constitutional Court had ordered that parliamentary elections be under full judicial supervision and introduced the "a judge for every voting box" rule. ${ }^{9}$ Since the ruling and presumably due to logistical constraints, parliamentary elections continued to be conducted in three stages. Figure 1 shows the geographic distribution of the three voting stages for the 2011/2012 People's Assembly elections. The elections in Egypt's 27 governorates were conducted with an equal number of nine governorates per stage and an average of around 1.5 million voters per constituency. ${ }^{10}$ In each governorate, one to four constituencies were formed, taking the governorate's population into consideration. Accordingly, the large in size but quite scarce in population frontier governorates - North Sinai, South Sinai, Red Sea, Marsa Matruh and New Valley - formed only one constituency, respectively, whereas Cairo was divided into four constituencies. The first election stage consisted of 16 party list constituencies, while the second and third voting stages consisted of 15 party list constituencies each. Interestingly, the results of each stage were announced directly after the end of the elections in each stage i.e. before the elections in subsequent stages took place. A more detailed analysis of the geographical breakdown and characteristics of the constituencies will follow in Section 3.4.

In our analysis of the determinants of voting outcomes, we focus only on the election outcomes that are based on proportional representation voting rule due to the following: First, single list elections could be more driven by the personality and personal history of competing candidates rather than by ideology, second, the candidates in single lists voting do not have to be affiliated to any party which makes it more difficult to pigeonhole their political orientation and third, by concentrating on proportional representation, it is easy to avoid bias due to strategic voting in the case of single list elections.

\footnotetext{
${ }^{9}$ See the Supreme Country constitutional ruling on case 22 in the thirteenth judicial year, published in the official gazette on July 22, 2000.

${ }^{10}$ The first election stage took place on 28-29 November 2011 in the governorates Cairo, Fayoum, Port Said, Damietta, Alexandria, Kafr El-Sheikh, Assiut, Luxor and the Red Sea. The second stage followed on 14-15 December 2011 in further nine governorates, namely Giza, Beni Suef, Menoufiya, Sharkiya, Ismailia, Suez, Beheira, Sohag and Aswan while the third and last stage took place on 10-11 January 2012 in Minia, Kalioubia, Gharbia, Dakahlia, North Sinai, South Sinai, Marsa Matruh, Qena and New Valley. As to majority voting elections in the 83 single district constituencies, each stage also included a potential run-off in the following week.
} 


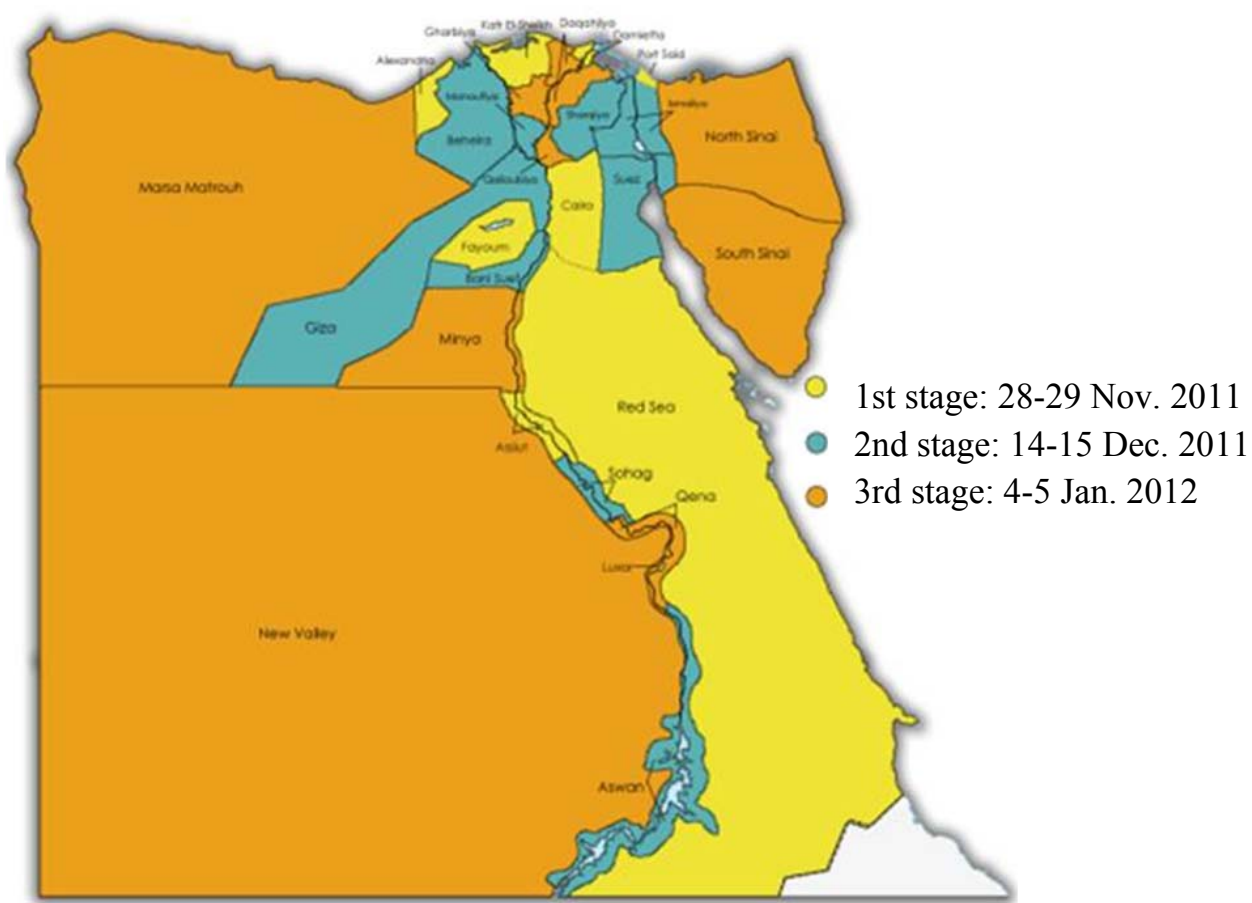

Figure 1 Egypt's three voting stages.

Source: IFES (2011)

\subsection{Parties and Electoral Blocks}

After the Egyptian uprising, party formation laws were loosened considerably. Parties can now be formed upon notice and advertisement. ${ }^{11}$ Next to the independent candidates, more than 50 parties took part in Egypt's first parliamentary elections. At the beginning of the coordination period, there were rather widespread initiatives for the creation of alliances and multi-party lists which have been more or less successful.

New and old parties have all positioned themselves according to a secular or Islamist ideology. It is interesting to note that Islamist parties support in broad lines the same liberal economic system as secular liberal parties. The secular parties in Egypt are divided into liberal and socialist secular parties whereby the former group is much larger than the latter. Focussing on the investigation of the main determinants of voting secular vs. Islamist, we

\footnotetext{
${ }^{11}$ The amended Article 40 on party formation law specifies that parties cannot be formed on a religious or sectarian basis. Parties also cannot be formed on the basis of race, colour, origin, geography or language. Furthermore, parties with any form of military shapes or units are prohibited. The new law specifies that a new party needs only the signature of 5,000 citizens from 10 of Egypt's 27 governorates to gain legitimacy and cancels government subsidies to political parties.
} 
abstract from outcomes driven by differences in economic ideology by taking only the group of liberal secular parties into account for our empirical analysis of secular voting.

In the following two subsections, we introduce the main political players of the postrevolutionary Egyptian parliament along the secular vs. Islamist dimension. We briefly present the history and main goals of each of the political parties and illuminate their avenues of public outreach. We categorize the main well-known players on the Islamist-secularspectrum according to two main sources: information published on each party's internet website and the party profiles on the Egypt's transition website by Carnegie Endowment for International Peace. ${ }^{12}$ Note that parties that were ideologically not easily allocated to the group of Islamist or the group of secular parties are disregarded in our benchmark analysis. In subsection 2.2.3, we shortly introduce the main players and characteristics of the remaining parties that we do not use in our empirical analysis. The parties that we manage to categorize in the Islamist or secular group of parties cover about $83 \%$ of votes on the constituency's average and an even higher percentage of the seats in parliament.

\subsubsection{Islamist political parties}

The main Islamist political parties, which have strong representation in the newly elected parliament, are the Muslim Brotherhood's Freedom and Justice Party (FJP) and the Salafi AlNour Party. Note that the combined share of voting for the FJP and the Al-Nour Party has amounted to an average of $62 \%$ at the constituency level.

The FJP was formed by the Muslim Brotherhood in May 2011 and is the dominant Islamist party in Egypt. ${ }^{13}$ Aware of the fears that surround its participation, the party defines itself as a "civil" party rather than an Islamic one. The term civil, however, is particularly vague as it can be brought under the same umbrella of the Muslim Brotherhood's slogan of "Islam is the solution". The Muslim Brotherhood has long been part of the Egyptian political process fielding candidates in the People's Assembly since 1984. Banned from forming a political party, it was presenting its candidates either under the auspices of other parties or as independent candidates. ${ }^{14}$ Building on more than two decades of political participation, the

\footnotetext{
${ }^{12} \mathrm{http}$ ://egyptelections.carnegieendowment.org/category/political-parties. Accessed on 30.05.2012.

13 The Muslim Brotherhood is one of the oldest and most widespread movements of political Islam. It was founded in 1928 by the Islamic scholar and school teacher Hassan Elbanna.

${ }^{14}$ The high point of the Muslim Brotherhood's electoral participation came in 2005, when its members, running as independents, won 20 per cent of the People Assembly's seats. See IFES notes on the 2005 People's
} 
FJP was able to participate in all voting districts and won 125 seats from the proportional vote segment. The FJP started the election campaign as the main party in the Democratic Alliance for Egypt, an alliance which should have consisted of both secular and Islamist leaning parties. However, coordination proved difficult with a large number of parties leaving the alliance, which in effect led to the FJP running its own list.

The Al-Nour Party was founded in 2011 following the January 2011 uprising. It was the first Salafi political organization to submit a request to be recognized as an official political party. Prior to the January 25 Egyptian Revolution, Salafis had not taken part in Egyptian political life. As Salafism has become associated with literal, strict and puritanical approaches to Islamic theology, they are considered much more conservative than the Muslim Brotherhood. Salafis have been reported to have wildly contradicting stances with regard to democracy and participation in public political life (see Brown, 2011). Despite the fact that Salafis do not show the same degree and history of organisation as the Muslim Brotherhood, the Al-Nour Party has participated in all party list constituencies except in South Sinai and the Red Sea. The Al-Nour Party was able to obtain 94 seats in the People's Assembly via the proportional vote.

To understand the support for Islamist groups and political parties, it is important to highlight the Islamist's methods of public outreach. Particularly, the Muslim Brotherhood has a strong history of political opposition. Muslim Brotherhood affiliated figures were forced to run as independents and suffered many arrests and condemnation as an "illegal organisation with ties to extremist groups". Nevertheless, Islamist outreach and mobilization took place in local mosques, community associations, informal study groups and networks. The Islamists have been widely known for their strong, historic and widely-spread social work such as operating low-cost hospitals, informal study programmes and other social services. Thus, they have enjoyed a good reputation amongst the poor, especially as state social services were illfunctioning and corrupt (see Wickham, 2002).

\subsubsection{Secular political parties}

In the following, we present the main secular and economically liberal Egyptian parties and blocks that ran for candidacy in Egypt's first post-revolution parliamentary elections. We

Assembly elections. http://www.ifes.org/egypt. Accessed on 01/08/2012. Strong repression by the government ensured that such success was not repeated in 2010. 
distinguish between two groups of secular political parties: parties which had been active prior to the uprising and parties and political groups which have emerged after the uprising. Secular parties managed to obtain on average around $21 \%$ of the proportional vote, which corresponds to 80 of 332 possible seats.

The New Wafd Party is one of the old, established secular political parties, seeking to find their place in post-uprising Egypt. The Wafd is the successor to the once powerful organization that was disbanded in 1952 by Nasser. The party was established in 1978 and emerged as one of several parties when Sadat introduced limited pluralism to the Egyptian political process. Due to its historical significance and reputation, it has been one of the main secular parties which have managed to select representatives in all but one party list constituency. The Wafd Party were able to obtain 39 seats.

The Ghad Party was founded in 2004 and was originally a splinter group of the Wafd Party. The party has a clearly secular orientation. It has also enjoyed some name-recognition when its founder, Ayman Nour decided to run for the presidency in Egypt's first multi-candidate presidential elections in 2005. Nour placed a distant second. ${ }^{15}$ The Democratic Front Party is another secular party, which has been active since the Revolution. It was founded in 2007 and defines itself as a civil party, which is secular in orientation. Both the Democratic Front Party and the Ghad Party participated in only 12 and 15 party list constituencies, respectively. They, however, have been unable to win any seats. Another secular party which has managed to organize party lists in all but three party list constituencies is the Reform and Development Party. The Reform and Development Party was founded in 2009 as an offshoot of the Democratic Front Party. However, it was only legalized after the revolution in May 2011. The Reform and Development Party was able to capture 9 seats.

The Egyptian Block is the most visible clearly secular party alliance that was initiated after the Egyptian uprising. It is an electoral party alliance that consists of the Free Egyptians Party at $50 \%$ participation, the Egyptian Social Democratic Party at $40 \%$ and the Taggamu Party at a $10 \%$ participation level of the party list. Note that both the Free Egyptians Party and the Egyptian Social Democratic Party are new parties that were founded after the Egyptian

\footnotetext{
${ }^{15}$ The Ghad Party also participated in the 2005 parliamentary elections but was only able to win one seat.
} 
uprising. The Block contested the elections in 42 party list constituencies and obtained 32 seats. $^{16}$

In contrast to the Islamist parties, secular parties have no history of social public outreach. In fact, there has been a strong division between the political and social sphere. There are grassroots political movements such as the April $6^{\text {th }}$ Youth Movement was already quite active even before the Egyptian revolution and secular in their orientation; however, they have opted for the development of general awareness campaigns against ex-regime remnants rather than an endorsement of a particular secular political party. ${ }^{17}$

\subsubsection{Other parties}

There are twenty eight more parties which took part in the parliamentary elections and put forward a party list in at least one constituency. The remaining parties received on average around $17 \%$ of the vote. They, however, cannot be treated as a homogeneous group as they have strongly divergent ideological backgrounds. In the following, we identify three groups in which one can categorize the remaining parties.

The first group are the ideologically centrist parties which have opted for the middle ground between the dimensions of secular and Islamist, not clearly associating with just one. Here, the main players are the Revolution Continues Alliance, which is an alliance comprising new leftist parties and revolutionary youth both from a secular and Islamist background, the $\mathrm{Al}$ Wasat Party, which is a moderate Islamist party that clearly states its adherence to a secular state but with Islamist leanings and the El Adl Party, which defines itself as a strongly centrist party. This group of parties were attributed 14 seats in the parliament.

The second group of parties one can identify are the offshoots of former ruling Mubarak's NDP, which have reorganized after the dissolution of the NDP party in April 2011. The campaign for catching regime remnants "emsek flol" identifies ten parties, which have on average managed to obtain $8 \%$ of the vote in each constituency and managed to fill 16 seats. ${ }^{18}$

\footnotetext{
16 In one constituency, Qena, the Free Egyptians Party and the Egyptian Social Democratic Party ran independently and not as part of a joint party list of the Egyptian Block.

17 Particularly widespread has been the „emsek flol“ (catch regime remnants) awareness campaign. See www.emsekflol.com. Accessed on 01.08.2012.

${ }_{18}$ According to the "emsek flol" website, the following parties are NDP offshoots: The Arab Egyptian Union Party, the Union Party, Modern Egypt Party, National Egypt Party, the Conservative Party, the New Independents, the Egyptian Citizen, the Human Rights and Citizenship Party.
} 
Thirdly, there are purely secular and leftist parties that have only managed to garner $1.2 \%$ of the vote. They consist mainly of the Socialist Party, the Omma Party, the Nasserist Party and the Free Socialists Party. A list of all other parties, the number of constituencies with their party list participation and proportional voting results on the constituencies' average can be found in Table A.3 of the Appendix. In the following section, we introduce our dataset and derive the main hypothesis underlying our analysis.

\section{Data and hypotheses}

\subsection{The dataset and dependent variables}

We have collected our data on voting outcomes from the official website of the Egyptian parliamentary elections $2011 / 2012$, which publishes the voting outcomes data on the electoral constituency level. ${ }^{19} \mathrm{We}$ focus on the total valid votes and the accrued votes by each party or parties' electoral alliance according to the proportional representative voting system in 46 electoral constituencies. Building on the analysis of section 2, we define two categories of parties;: (1) Islamist parties, i.e. parties with an Islamist ideology and political orientation and (2) secular and economically liberal parties i.e. parties indicating a secular ideology and liberal economic orientation. On average, our two categories cover about $83 \%$ of votes at the constituency level (Table 1). The group of Islamist parties contains the Freedom and Justice Party and the Al-Nour Party while the group of secular parties includes the Egyptian Block, the New Wafd Party, the Reform and Development Party, the Democratic Front Party and the New Ghad Party.

Our dependant variables are the share of votes for Islamist parties on the one hand and secular parties on the other, both at the constituency level. Table 1 includes summary statistics for both dependant variables. The means of both variables reveals the popularity of Islamist parties in Egypt, reaching about $62 \%$ on the constituency's average, while the average of votes accruing to the secular group of parties reaches only $21 \%$. However, voting to each group strongly varies across constituencies. The votes for the Islamist parties range between 36 and $85 \%$, and voting for the secular parties ranges between 6 and $48 \%$.

\footnotetext{
${ }^{19}$ http://www.elections2011.eg/ Accessed on 19.04.2012.
} 
Table 1: Summary statistics of dependant variables

\begin{tabular}{lccccc}
\hline Variable & Obs. & Mean & $\begin{array}{c}\text { Std. } \\
\text { Dev. }\end{array}$ & Min. & Max. \\
\hline $\begin{array}{l}\text { Islamist parties' } \\
\text { share of votes }\end{array}$ & 46 & 61.94 & 10.34 & 35.69 & 85.07 \\
$\begin{array}{l}\text { Secular parties } \\
\text { share of votes }\end{array}$ & 46 & 20.54 & 8.45 & 5.61 & 48.02 \\
\hline
\end{tabular}

For our covariates, we use the most recent Population and Housing Census data for the year 2006 by the Central Agency for Public Mobilisation and Statistics (CAPMAS), Egypt's official statistics agency. The census contains data on 346 districts and conglomerations of villages (markaz) in Egypt. Using the census data, we construct a dataset on the socio-economic background as well as the economic and labour market structure of the 46 electoral constituencies to match the level of aggregation of the available data on election outcomes. Specifically, we merge both datasets by aggregating the 346 districts according to their designated constituency. We present our covariates and main hypothesis in the following section.

\subsection{Independent variables and hypotheses}

The economic literature on voting outcomes has focused on the economic voting hypothesis, which states that voters hold the incumbent government responsible for economic outcomes. ${ }^{20}$ Given the fact that our analysis is based on the first democratic elections after the Egyptian revolution, our data does not allow for a clear identification of the economic voting hypothesis. We cannot observe how a change in economic factors has impacted the support for a particular party. The election outcomes, however, can be interpreted as prospective in nature. The notion that countries in transition lean more towards prospective rather than retrospective voting has been analysed in Fidrmuc (2000). He shows empirically that voters in transition economies, in his case Central and Eastern European countries during their transition, vote for parties in correspondence with their future best interest. Despite the fact that we cannot directly apply the economic voting hypothesis to our data, this literature has shed some light on several dimensions that impact voting outcomes which we call upon to in our analysis below.

\footnotetext{
${ }^{20}$ For a survey of the economics and political science literature, see Lewis-Beck and Stegmaier (2000).
} 
Given the context of our underlying election, we theoretically identify three dimensions which can affect voting outcomes: we capture the socio-economic background of a constituency, the economic and employment structure of a constituency and the electoral institutional framework. In the following, we will motivate these three dimensions, introduce our groups of explanatory variables for each category and present our related hypotheses.

\subsubsection{Socio-economic Background}

Swank and Eisinga (1999) analyse economic voting in the context of a multi-party system and proportional representative voting. They show that voting outcomes are strongly influenced by non-economic factors. Their main argument lies in the fact that in multi-party systems individual parties receive votes in the elected body in proportion to the percentage of votes they receive in elections. This type of system, wherein each party comes to represent a different group of voters rather than competing for the median voter, changes the nature of the competition for voters, (see Norris, 2005). Thus, apart from economic outcomes, socioeconomic variables are likely to affect election outcomes.

With regard to the socio-economic determinants, we attempt to capture the following dimensions: education, poverty, female participation in the labour force and age structure. Islamist groups in Egypt used to provide social, health and educational services where the former regime showed provision weakness and ineffectiveness. Given their strong historical social outreach (Wickham, 2002), we expect to find a higher support of Islamist parties in constituencies with higher poverty rates. As a proxy for a constituency's poverty level, we use the share of a constituency's population in per cent that does not have access to public sanitation networks.

Erle et al. (2011) have explored voting intention based on a survey conducted by the AlAhram Centre for Political and Strategic studies in 22 Egyptian governorates prior to the parliamentary elections. Their cluster analysis shows a distinct difference in the voting intention of the constituencies according to their socio-economic profile, with rich clusters (defined as having low illiteracy rate and high access to public sanitation) supporting secular parties while poorer clusters (high illiteracy rate and low public sanitation access) show more support for the Islamist parties. As did Erle et al. (2011), we take up both dimensions of the socio-economic profile of poverty and education. However, we allow for a more specific 
ceteris paribus estimation and isolation of the effects of the socio-economic profile on the voting outcome based on a multivariate regression analysis. We capture the level of education in a constituency through the illiteracy rate and university education. Illiteracy rate is measured as the share of illiterates in the population aged 10 years and above ${ }^{21}$ in per cent. University education measures the fraction of a constituency's population above 10 years of age with a university education in per cent.

Furthermore, we include the share of women in the labour force as a proxy for gender-balance and modernization. One might posit that a higher share of women in the labour force is likely to correlate with lower degrees of conservatism. This variable also enables the identification of a possible gender effect on voting outcome. This is particularly interesting, if one takes into account that the Salafi political movement has strongly conservative views on women's participation in public life and the work force (see Brown, 2011). For example, to circumvent the regulation that one female should be included in each admissible party list, female candidates were put at the end of each list and in some cases, photos of the female candidate, were obscured by a flower or an inanimate object in campaign flyers. ${ }^{22}$

Finally, we account for the constituency's age structure in describing its socio-economic profile. Following Swank and Eisinga (1999), we control for the different age groups in our regression analysis. Our regressions employ three age groups such as are reported in the census data by CAPMAS: the fraction of population aged between 15 and 45 years, the share of population aged between 45 and 60 years and the fraction of population aged 60 years and above, all in per cent. ${ }^{23}$ Given the timing of our data, an analysis of the dominant age groups might shed some light on some generational conflicts.

\subsubsection{Economic and employment structure}

Capturing the economic and employment structure in Egypt is particularly challenging, especially at the constituency level. We include unemployment rates at the constituency level, which has had a significant positive impact on Islamist party voting in a number of empirical

\footnotetext{
${ }^{21}$ Note that we use the population above 10 years due to data availability in the Egyptian Census.

${ }^{22} \mathrm{http}: / /$ english.al-akhbar.com/node/1505. Accessed 02.08.2012

${ }^{23}$ Note that the census took place in 2006 while the elections took place in December 2011 and January 2012. The definition of the years in each age group is restricted by the categorization in the reported data by CAPMAS.
} 
studies on Turkish elections (e.g. Akarca and Tansel, 2006; Genc et al., 2005; and Baslevent et al., 2005).

Furthermore, we also analyse how the share of public sector employment affects voting outcome. In this case, one can argue that public sector employees are more directly affected by changes in the political will of the government. Furthermore, the quality and accuracy of data on public sector employment should be more reliable than that of data on private or informal employment. ${ }^{24}$

\subsubsection{Electoral institutional framework}

An important dimension of the economic voting hypothesis is its sensitivity to the electoral and political framework. For example, Powell and Whitten (1993) show - in their crosscountry comprehensive study of economic voting in 102 elections in 19 industrialized economies - that considerations of the ideological image of the government, its electoral base and the clarity of its political responsibility play important roles in the voting outcome.

An interesting particularity of the Egyptian parliamentary elections is the fact that the voting results from each voting stage in the sequential voting setup were publicly announced after the conclusion of each round. Taking our cue from Morton and Williams (1999), who, using laboratory experiments, specifically analyse the impact of sequential voting on voting outcomes, our analysis tracks how the announcement of each round affected voting in the subsequent voting stages. ${ }^{25}$ The literature on sequential voting that might arise due to the sequentiality of the vote introduces two possible behavioural effects on voters: the bandwagon and the underdog effect (Simon, 1954; Fleitas 1971; Brown and Zech 1973; Garntner, 1976).

The bandwagon effect mainly captures the notion that an undecided voter will vote for a party which is already winning, while the underdog effect captures the notion that an undecided voter will vote for a party which is currently losing. More specifically, undecided voters' decisions to vote for the announced winner of a previous stage of the vote would be equivalent to the bandwagon effect, whereas, in the underdog effect an undecided voter would decide against the winner of a previous voting stage and for the underdog of the first round.

\footnotetext{
${ }^{24}$ Schneider (2002) estimates that the informal sector in Egypt constitutes approx. 35.1\% of national GDP.

${ }^{25}$ Morton and Williams (1999) posit that later-stage voters can use early voting outcomes to infer information about the candidates (i.e. their winning probabilities) and, thus, make choices that better reflect their preferences.
} 
Given the varying degrees of organisation attributed to each of the parties, we determine whether the sequential procedure of voting has made it harder or easier for the less organized secular parties to contest the elections against the more organised Islamist parties and offshoots of Mubarak's defunct National Democratic Party (NDP). This is particularly interesting given the fact that the outcome of the parliamentary elections would also shape the form of the constitutional committee. As such, it might be useful to see whether voters given the announcement of previous outcomes decided to vote for the winning party or opted for the underdogs and as such strengthen diversity in the Parliament. Thus, we use the first stage of the vote as a reference group and include two dummy variables to control for the second and third stages of the election.

\subsection{Some descriptives}

We start our analysis by providing some descriptive analysis of our data set. Table A.1 shows summary statistics for our explanatory variables. Similar to the dependant variables, our independent variables show a considerable amount of variation. The last two columns of Table A.1 present Pearson's correlation coefficients of our explanatory variables with our two dependant variables. Regarding the share of votes for Islamist parties, relatively high positive correlations exist with illiteracy rate (0.36), while strongly negative associations are found with university education (-0.40) and the fraction of the younger age group 15-45 years (0.41). As pertains to the share of votes for secular parties, the data reveals a strongly positive correlation with university education (0.45), the younger age group of 15-45 years (0.44) and the female share in labour force $(0.35)$. Note that the correlation coefficients regarding poverty are quite small and insignificant. Since bivariate correlations are often misleading, a multivariate analysis is required to explain cross-section variations in voting outcomes.

Before we introduce our empirical approach and the results of our multivariate analysis in the following section, we further analyse the sequential voting procedure by testing for systematic differences in the observed constituencies by stage. In Table A.2, we present the means by stage for all the dependent variables that were introduced in Table A.1 and introduce a variable on the average distance from Cairo by stage. If the choice of constituencies per stage was systematic rather than random, the aggregation of the covariates according to stages might show a concentration of constituencies according to types. For example, constituencies 
in the first stage of the vote would have systematically different characteristics than in stage 2 and stage 3 .

Table A.2, however, shows that for the majority of variables, there are no extreme differences between the characteristics of the constituencies of each stage according to observables. These simple observations are further confirmed when using the Wilcoxon Rank-sum test (1945) to determine if the stages are significantly different from one another. Only in the cases of university education and sanitation does the rank-sum test show a significant difference between the different stages. More specifically, 4 out of the 27 performed pair-wise tests show a significant difference between the stages.

In Figure 1, we showed the geographical distribution of the stages. It is easy to ascertain that the choice of grouping the constituencies according to stages was not driven by geography. For example, the constituencies of the Nile Delta are distributed amongst all stages. In an effort to determine how far each of the stages was from the centre, we have collected the geographical distance from each constituency to Cairo in kilometres $(\mathrm{km})$. In the cases in which the governorates were not split into more than one constituency, we use the distance from the central post office to Cairo and in the cases in which the governorates were split into different constituencies, we use the distance from the most populous district or village in each constituency to Cairo. Taking the average of the distances per stage, one can see that the constituencies of each stage have on average not been farther away from Cairo, with the difference in average distances to Cairo amounting to only $67 \mathrm{~km}$. Thus, we feel confident that the introduction of stage dummies would effectively capture timing differences and not regional or systematic differences.

\subsection{Data limitations}

While our data set is novel and unique, it is important to mention that our empirical investigation faces several methodological limitations due to data constrains.

First, we cannot analyse the determinants of voting decisions on the individual level, since no individual data on the voting decisions can be available according to the secrecy of the ballot. Given this, we are aware of the "ecological fallacy" and do not intend to make any inference of our results on the individual level.

Second, our analysis is limited by the level of aggregation of the officially reported data on voting outcomes on the level of 46 constituencies. Reporting the voting outcome data on a 
more disaggregated level would have enabled us to conduct our analysis on a more disaggregated level. It is important to note, however, that other than in the urban cities of Cairo, Giza and Alexandria, constituencies are strongly homogeneous.

Third, our set of explanatory variables on the economic and employment structure is limited to data that we can capture at the constituency level. Exploring the explanatory power of further variables such as the division of economic sectors or public and private investments would only be possible in an analysis on a more aggregated level such, as on the governorate level. However, this would be at a high cost for our model as it reduces the number of observations to only 27 governorates.

Fourth, we are not able to include a variable on the share of religious affiliation in constituencies as no statistics on religious affiliations are published in Egypt. Neither are we able to take the electoral campaign budgets of parties into account as parties in Egypt are not required to publish such information.

\section{Estimation approach and results}

We analyse the determinants of voting outcomes using two cross-sectional regressions at the constituency level, one for Islamist parties' share in votes and one for secular parties share in votes. Our descriptive analysis above showed that there is considerable variation in voting outcomes for both groups of parties across constituencies as well as in the constituencies' characteristics. The estimation method is ordinary least squares. Our estimation approach is based on general-to-specific modelling (Hendry 2001), which allows us to identify the main determinants of voting outcomes, taking the limited sample size into account and avoiding path dependencies in the elimination process of insignificant variables. Thus, in both regression models, we first estimate a general model with eleven explanatory variables and test for the applicability of the OLS assumptions. We then apply a consistent testing-down process to increase estimation efficiency by reducing the number of variables in the model. The specific model finally contains the variables that remain after the reduction process and of which one can presume that their elimination would violate the underlying statistical assumptions. Our interpretation of the results is based on the more efficiently-estimated reduced model. We also estimate the standardized coefficients of the reduced model to compare the relative strengths of the various regressors within each model. 
Table 2 presents the regression results of our model on determinants of voting for Islamist parties while Table 3 contains the estimates of the model on the determinants of voting for secular parties. In both tables, the coefficient estimates and standard errors (SE) of the general model are presented on the left part of the table (first and second columns) while those of the reduced model in addition to the standardized coefficient estimates are given in the right part of the table (third to fifth columns).

Table 2: Determinants of voting for Islamist parties

\begin{tabular}{|c|c|c|c|c|c|}
\hline \multirow{2}{*}{$\begin{array}{l}\text { Model } \\
\text { Variables }\end{array}$} & \multicolumn{2}{|c|}{$\begin{array}{l}\text { (1) General Model: } \\
\text { OLS }\end{array}$} & \multicolumn{3}{|c|}{ (2) Reduced Model: OLS } \\
\hline & Coefficients & $\begin{array}{l}\text { Standard } \\
\text { Errors }\end{array}$ & Coefficients & $\begin{array}{l}\text { Standard } \\
\text { Errors }\end{array}$ & $\begin{array}{c}\text { Standardized } \\
\text { coefficients }\end{array}$ \\
\hline \multicolumn{6}{|l|}{ a) Socio-economic background } \\
\hline University education & $-1.833 * *$ & 0.680 & $-1.632 * * *$ & 0.525 & $-0.752 * * *$ \\
\hline Illiteracy rate & 0.642 & 0.392 & $0.838 * * *$ & 0.282 & $0.711 * * *$ \\
\hline No access to public sanitation & $-0.299 * * *$ & 0.090 & $-0.344 * * *$ & 0.077 & $-0.983 * * *$ \\
\hline Women in labour force & 0.386 & 0.421 & & & \\
\hline Age group $15-45$ & -0.583 & 0.546 & & & \\
\hline Age group 45-60 & 1.653 & 1.582 & & & \\
\hline Age group above 60 & $-3.682 * *$ & 1.654 & $-1.634^{*}$ & 0.971 & $-0.224 *$ \\
\hline \multicolumn{6}{|l|}{$\begin{array}{l}\text { b) Economic and employment } \\
\text { structure }\end{array}$} \\
\hline Unemployment rate & -0.093 & 0.543 & & & \\
\hline Public employment & 0.586 & 0.433 & $0.912 * * *$ & 0.320 & $0.412 * * *$ \\
\hline \multicolumn{6}{|l|}{$\begin{array}{l}\text { c) Electoral institutional } \\
\text { framework }\end{array}$} \\
\hline Dummy: $2^{\text {nd }}$ election stage & -0.922 & 3.281 & & & \\
\hline Dummy: $3^{\text {rd }}$ election stage & -4.696 & 3.281 & $-4.850 *$ & 2.578 & $-0.222 *$ \\
\hline Constant & $97.786^{* *}$ & 42.900 & $73.216^{* * *}$ & 15.001 & \\
\hline (1) No. of observations & 46 & & & 46 & \\
\hline (2) Standard error of regression & 7.88 & & & 7.655 & \\
\hline (3) $R^{2}$ & 0.56 & & & 0.526 & \\
\hline (4) Adjusted $\mathrm{R}^{2}$ & 0.41 & & & 0.453 & \\
\hline \multicolumn{6}{|l|}{ (5) Schwarz information } \\
\hline criterion & 352.5 & & & 336.997 & \\
\hline (6) Test of joint significance & $\mathrm{F}(11,34)=$ & $3.95 * * *$ & & $6,39)=7.20$ & $0 * * *$ \\
\hline (7) Testing-down restriction & $\mathrm{F}(5,34)=$ & $=0.55$ & & n.a. & \\
\hline (8) Normality test & $\mathrm{W}=0$. & .984 & & $\mathrm{~W}=0.990$ & \\
\hline (9) Heteroscedasticity test & Chi2 $(1)=$ & $=0.80$ & & Chi2 $(1)=0$. & \\
\hline (10) RESET test & $\mathrm{F}(3,31)=$ & $=1.48$ & & $(3,36)=1$ & \\
\hline
\end{tabular}




\subsection{Voting for Islamist parties}

We start by regressing all explanatory variables on the Islamist parties' share of the votes. Our group of eleven covariates in the general model (1) in Table 2 is jointly significant at the $1 \%$ level (see line (6)). The fit of the model is reasonably high; the general model explains about $56 \%$ of the variation in voting for Islamist parties across constituencies. None of the diagnostic tests for non-normality, heteroscedasticity, and specification error, which we report in lines (8) - (10), indicate a violation of OLS assumptions. Consequently, we may conclude that model (1) is a congruent representation of the data-generation process.

Conducting a consistent testing-down process, the elimination of five variables cannot be rejected at any reasonable level as indicated by the F-test in line (7), leading to the reduced model (2) with six explanatory variables jointly significant at the $1 \%$ level. The reduced model passes all diagnostic tests and, thus, can be regarded as a congruent representation of the data-generation process. The fit of the model is worse - as expected - because of the lower number of explanatory variables in the model, however, our three model selection criteria (Adjusted $\mathrm{R}^{2}$, standard error of regression and Schwarz information criterion) improve compared to the general model.

Our results in Table 2 indicate that all three groups of explanatory variables, previously highlighted in section 3, significantly contribute in explaining Islamist parties' share of the vote. In the following, we discuss the impact of each of the variables separately.

Concerning the socio-economic background, we find that education, poverty and the age structure matter for explaining the variation in Islamist voting outcomes. As for education, the coefficients of both illiteracy rate and the percentage of university graduates are statistically significant at $1 \%$ level. The results suggest that constituencies with a higher level of education voted significantly less for Islamist parties. Precisely, a 1 percentage point (pp) higher share in university graduates is associated with a $1.6 \mathrm{pp}$ lower share in votes for Islamist parties. A ceteris paribus increase in the illiteracy rate by $1 \mathrm{pp}$ is positively correlated with a $0.8 \mathrm{pp}$ higher share in votes for Islamist parties. With respect to our poverty indicator, we observe that a $1 \mathrm{pp}$ higher lack of access to public sanitation networks lowers the share of Islamist voting by $0.3 \mathrm{pp}$. This effect is significant at the $1 \%$ level. 
Hence, our results suggest that education and poverty do not necessarily go hand in hand when it comes to voting outcomes. Constituencies with a (ceteris paribus) lower level of education vote more in favour of Islamist parties. Having education controlled for, we find that poor constituencies vote less in favour of Islamist parties. The negative effect of poverty on supporting Islamist parties is quite surprising due to the historically strong social outreach of the Muslim Brotherhood and the strong charity work by Islamist movements in Egypt, in general. The results for education, however, are not particularly surprising given the information dissemination and propaganda in favour of political Islam in Friday prayers and in mosques more generally which are major sources of information and knowledge for less educated and non-educated voters. Note that the standardized coefficients reveal that poverty and education have the strongest impact on the share-of votes for Islamist parties.

We further find that women's participation in the labour force does not have a significant impact on Islamist voting. This finding is in line with the recent Pew Global Attitudes Survey (2012) on Islam and modernity in Egypt, wherein respondents do not see conflict between the two.

Regarding the group of age variables, the variable that captures the fraction of old population above 60 years is the only variable that survives the model reduction and is negatively associated with voting for Islamist parties. Specifically, constituencies with a $1 \mathrm{pp}$ higher share of population older than 60 years are correlated with a $1.6 \mathrm{pp}$ lower Islamist parties' share in votes at a significance level of $10 \%$. We are cautious in interpreting this result as we wish to avoid the 'ecological fallacy' especially as this age group is quite small. ${ }^{26}$ However, our result indicates that old constituencies - in terms of the population's age - vote significantly less for Islamist parties.

In terms of the economic and employment structure of constituencies, the unemployment rate turns out to be insignificant for the voting outcomes of Islamist parties and is not a part of our reduced model. Furthermore, our results indicate that a higher share of public employment is positively associated with a higher Islamist voting outcome at a $1 \%$ significance level. More precisely, constituencies with a 1 pp higher shareof public employment show a significantly

\footnotetext{
${ }^{26}$ It is the smallest of the three included age groups and represents an average of $60 \%$ of each constituenc's
} population(see Table A.1). 
higher share, 0,9 pp, of Islamist voting. Egypt's relatively large public sector is characterised by high job security on the one hand but low wages on the other (Said, 2012). Many strikes have been documented before and after the revolution. Our result could be likely driven by the urge of public sector employees to secure better (payment) conditions through a possible radical change in political will without the fear of losing their jobs.

Employing the variable on reported private employment instead, our results show that constituencies with a higher share of private employment are significantly negatively associated with Islamist voting. ${ }^{27}$ The results of this regression can be found in the Appendix (Table A.5, specification (1)). Specifically, constituencies with a 1 pp higher fraction of private employment show a lower support for Islamist parties by $0.4 \mathrm{pp}$ at the $10 \%$ significance level. Reasons why private-sector-intensive constituencies show lower support for Islamist parties could include the fear of the loss of tourists in Egypt( as tourism is a major sector of Egypt's private sector economy), the fear of losing foreign investments in Egypt and possible major changes in the banking financial system under an Islamic political regime.

Finally, regarding the electoral institutional framework, we find the coefficient of the dummy variable for the third stage of the parliamentary elections to be negative and statistically significant at the $10 \%$ level. This implies a ceteris paribus worse result for Islamist parties in the election's third stage by about $5 \mathrm{pp}$. Thus, we do not find a "bandwagon effect" at the third and final stage of elections, which indicates that voters opted for less dominance of one political orientation and ideology in parliament in reaction to the announcements of the results of prior election stages. The motivation of this voting behaviour could be the urge for more diversification in parliament, especially due to its task to elect the committee who will write the new constitution. In the following section, we present the estimation results of secular voting.

\subsection{Voting for secular parties}

Table 3 presents the regression results with regard to the share of votes accrued by the secular parties. The estimation approach is identical to the Islamist voting outcome regressions. Again, the eleven explanatory variables in our general model (1) are jointly significant at the $1 \%$ level as shown at the lower part of Table 3 . The fit of the model is even higher compared

\footnotetext{
${ }^{27}$ Note that the public and private sector employment variables do not even closely add up to $100 \%$. However, including both variables simultaneously in the model is not possible due to multicollinearity.
} 
to the model on Islamist voting. Our model explains about $60 \%$ of variation in secular parties' share in voting. As reported in lines (8) - (10), our model passes the diagnostic tests for normality, heteroscedasticity, and specification. Thus, we may conclude that model (1) is also a congruent representation of the data-generation process which allows estimation with OLS.

We increase the model efficiency by the elimination of four variables. Our reduced model (2) of Table 3 includes seven variables that are jointly significant at $1 \%$ level and whose inclusion in the reduced model is necessary to ensure that the testing-down restriction is not rejected by the data. Notice that the fit of the underlying reduced model only minimally deteriorates and remains quite high. Our efficient reduced model explains about $59.8 \%$ of the variation in support for secular parties and shows improvement according to the three model selection criteria (Adjusted $\mathrm{R}^{2}$, standard error of regression, Schwarz information criterion).

The estimation results show a similar picture to the Islamist voting outcomes when it comes to the main drivers of the results. However, it is important to note that the estimates for secular voting do not constitute a mirror image of Islamist voting. We focus in our interpretations on the differences in results compared to the Islamist's share of the votes.

As in the case of voting for Islamist parties, the socio-economic background of a constituency seems to be a major contributing factor in explaining the support for secular parties. The impact of university education and poverty is in line with our results on Islamist voting i.e. the coefficients are opposite in sign. Both are significant at the $1 \%$ level and - looking at standardized coefficients - have the strongest effect on support for secular parties. Our results indicate that constituencies characterized by a higher share of university graduates show greater support for secular parties and, poor constituencies that, when holding education constant seem to be more in favour of secular parties. Different from our results on Islamist voting, we find that the illiteracy rate is insignificant and not a part of our reduced model.

The female share in labour force cannot be excluded from our reduced model without violating the underlying statistical assumptions. This variable is, thus, a part of our reduced model (the p-value is 0.12 ). The result suggests a higher support for secular parties in constituencies with a more gender-balanced labour market. 
Table 3: Determinants of voting for secular parties

\begin{tabular}{|c|c|c|c|c|c|}
\hline \multirow{2}{*}{$\begin{array}{l}\text { Model } \\
\text { Variables }\end{array}$} & \multicolumn{2}{|c|}{$\begin{array}{l}\text { (1) General Model: } \\
\text { OLS }\end{array}$} & \multicolumn{3}{|c|}{ (2) Reduced Model: OLS } \\
\hline & Coefficients & $\begin{array}{l}\text { Standard } \\
\text { Errors }\end{array}$ & Coefficients & $\begin{array}{l}\text { Standard } \\
\text { Errors }\end{array}$ & $\begin{array}{c}\text { Standardized } \\
\text { coefficients }\end{array}$ \\
\hline \multicolumn{6}{|l|}{ a) Socio-economic background } \\
\hline University education & $1.385 * *$ & 0.531 & $1.355 * * *$ & 0.428 & $0.764 * * *$ \\
\hline Illiteracy rate & -0.025 & 0.306 & & & \\
\hline No Access to public sanitation & $0.229 * * *$ & 0.071 & $0.233 * * *$ & 0.057 & $0.813 * * *$ \\
\hline Women in labour force & 0.445 & 0.328 & 0.471 & 0.291 & 0.254 \\
\hline Age group 15-45 & $0.949 * *$ & 0.426 & $0.965 * * *$ & 0.351 & $0.425 * * *$ \\
\hline Age group 45-60 & -0.210 & 1.235 & & & \\
\hline Age group above 60 & 2.086 & 1.291 & $1.826^{*}$ & 0.908 & $0.306^{*}$ \\
\hline \multicolumn{6}{|l|}{$\begin{array}{l}\text { b) Economic and employment } \\
\text { structure }\end{array}$} \\
\hline Unemployment rate & -0.109 & 0.424 & & & \\
\hline Public employment & -0.545 & 0.338 & $-0.528 * *$ & 0.242 & $-0.292 * *$ \\
\hline \multicolumn{6}{|l|}{$\begin{array}{l}\text { c) Electoral institutional } \\
\text { framework }\end{array}$} \\
\hline Dummy: $2^{\text {nd }}$ election stage & 0.718 & 2.561 & & & \\
\hline Dummy: $3^{\text {rd }}$ election stage & 1.454 & 2.560 & 1.129 & 1.979 & 0.063 \\
\hline Constant & $-63.483 *$ & 33.489 & $-67.276^{* * *}$ & 21.293 & \\
\hline (1) No. of obser & 46 & & & 46 & \\
\hline (2) Standard error of regression & 6.125 & & & 5.837 & \\
\hline (3) $R^{2}$ & 0.600 & & & 0.598 & \\
\hline (4) Adjusted $\mathrm{R}^{2}$ & 0.470 & & & 0.523 & \\
\hline \multicolumn{6}{|l|}{ (5) Schwarz information } \\
\hline criterion & 329.75 & & & 314.693 & \\
\hline (6) Test of joint significance & $\mathrm{F}(11,34)=$ & $4.63 * * *$ & & $7,38)=8.06$ & $* * *$ \\
\hline (7) Testing-down restriction & $\mathrm{F}(4,34)=$ & $=0.05$ & & n.a. & \\
\hline (8) Normality test & $\mathrm{W}=0 . \mathrm{C}$ & 977 & & $\mathrm{~W}=0.978$ & \\
\hline (9) Heteroscedasticity test & $\operatorname{Chi} 2(1)=$ & $=0.02$ & & $\operatorname{Chi} 2(1)=0$ & .04 \\
\hline (10) RESET test & $\mathrm{F}(3,31)=$ & $=1.95$ & & $(3,35)=2$. & \\
\hline
\end{tabular}

Notes: see Table 2. Dependent variable is the share of votes accrued to secular parties.

Furthermore, we find evidence that suggests that a higher share of the age group 15-45 years in population is positively associated with higher support for secular parties at the $1 \%$ significance level. Precisely, constituencies with a higher youth intensity of $1 \mathrm{pp}$ show a significantly higher support for secular parties by $1 \mathrm{pp}$. This result is interesting for various reasons: First, the age group 15-45 years is the largest age group in the population, forming $50 \%$ of the population on the constituency's average. Second, this result is striking as it can be interpreted in such a way that suggests that youth disgruntlement has not resulted in higher support for Islamist political parties. We further find the effect of the variable capturing the 
share of old population above 60 years to be in line with our previous results. It is positively correlated with voting for secular parties at the $10 \%$ level.

As for the economic and employment structure of constituencies, we again find unemployment to be insignificant, as in our regression on Islamist voting. Public-sectorintensive constituencies show a significantly lower support for secular parties. This finding is in line with the result derived from the model on Islamist voting. A higher share of public employment by $1 \mathrm{pp}$ is correlated with a decrease in support for secular parties by $0.5 \mathrm{pp}$ at the $5 \%$ significance level. However, we find the share of private employment to be insignificant for secular voting as shown in specification (1) of Table A.6.

Regarding the electoral framework, we find no effect of announcing the results of completed electoral stages on voting for secular parties in subsequent stages. This finding indicates that the significantly lower support of Islamist parties in the final electoral stage that we show in our previous model does not go hand in hand with a higher support of secular parties in the final stage. ${ }^{28}$

\section{Robustness checks}

In the following, we conduct a series of robustness checks to determine the sensitivity of our results through changes in the estimation method and the specifications of explanatory variables.

Given the fact that our two sets of regressions stem from the same election results sheet, we allow for a correlation of error terms of both regressions within our estimations. Consequently, we re-estimate the general models of Tables 4 and 5 using seemingly unrelated regressions (SUR). The results of the SUR estimation are reported in Table A.4 of the Appendix. As both OLS general models include the same set of explanatory variables, the SUR coefficient results are identical to those from our OLS models. The standard errors are slightly smaller, leading to a modest increase in the t-statistics. Thus, the variables that are marginally insignificant in model (1) become significant at the $10 \%$ level using SUR. This is the case for the variables "illiteracy rate" and " 3 rd election stage" on Islamist voting and the

\footnotetext{
${ }^{28}$ Further analysis has shown that this reduction in support for Islamist parties has not benefitted a particular group of parties, but that this decrease in support meant a higher share for almost all other parties competing in the elections.
} 
variables "age group above 60" and "public employment" on secular voting. Their statistical significance is consistent with the results of our reduced models in Tables 4 and $5 .^{29}$

As the socio-economic dimension of a constituency seems to have the strongest impact on voting outcomes, we conduct a couple of robustness checks on the education and poverty level indicators. First, we include an interaction term of illiteracy and our poverty proxy. One might posit that poverty has a different effect on voting outcomes depending on the constituency's educational level. Thus, we investigate whether our results are robust to including an interaction term (illiteracy*No public sanitation) in our regression models. ${ }^{30} \mathrm{We}$ find the interaction term to be insignificant in both regression models. Our results on education and poverty remain robust (see specification (2) of Tables A.2 and A.3 in the Appendix). Second, we check the robustness of our results when modifying our indicator on the lack of education. Instead of "illiteracy rate", we use the variable "No educational degree" which captures the share of population that does not hold any certified education. Consequently, this variable captures a higher share of the population, namely the formally uneducated population. ${ }^{31}$ Our results are quite robust and remain nearly unchanged (see specification (3) in Tables A.2 and A.3).

Furthermore, we have used two strategies to determine the robustness of the implications of the sequential voting procedure. In specification 4 of Tables A.2 and A.3, we use the reduced models of Tables 4 and 5, respectively, but restrict our dataset to the constituencies of stage 2 and stage 3 only. Note that this decreases the number of underlying observations to 30 observations only. The rationale behind this approach stems from the observation that the constituencies in stages 2 and 3 are strongly similar (Table A.2). The results of this estimation further confirm our finding concerning the dummy variable for stage 3. It remains significant and almost unchanged in magnitude as regards the voting share for Islamist parties. The second approach to determine the robustness of the stage 3 result is the inclusion of a variable capturing the constituency's distance from Cairo in the specific model. This variable should

\footnotetext{
${ }^{29}$ Re-estimating the reduced models in Tables 4 and 5, which slightly differ in terms of explanatory variables using SUR, shows that our results hold up very well. The variables " 3 rd election stage" and "female participation in labour force" are now even significant at the 5\% level for Islamist voting and secular voting, respectively (results available upon request).

${ }^{30}$ We center both variables by subtracting their means before computing the interaction term.

${ }^{31}$ Note that in the robustness check for secular voting in Table A.6, we employed "No educational degree" in our model in addition to the seven variables of the reduced model as -other than in the case of Islamist voting- the variable "illiteracy rate" is not a part of the reduced model for secular voting (see Table 3). We find "no education degree" to be insignificant as well.
} 
be able to control for the geographic characteristics and distance from the capital in our regressions. The results of this estimation can be found in specification (5) of Tables A.2 and A.3 of the Appendix. For Islamist voting, the distance variable is significant at the $10 \%$ level, implying that the voting share for Islamist parties decreases by $1 \mathrm{pp}$ when the distance to Cairo increases by $100 \mathrm{~km}$. Nevertheless, the estimated stage 3 dummy variable remains robust and significant which further confirms our results with regard to the implications of the sequential voting procedure. ${ }^{32}$

\section{Conclusion}

This paper contributes to the empirical literature on voting in transition economies, the literature on political Islam and the literature on sequential voting. By using a novel dataset, our multivariate analysis of the outcome of Egypt's first elections after the Arab Spring has brought a number of interesting results and implications to light. We show that the socioeconomic background and the economic and employment structure of constituencies as well as the sequential voting procedure determine the voting outcomes in a statistically significant and economically relevant way.

Our analysis reveals that education and poverty are the most important aspects for determining voting outcomes. In fact, constituencies with a higher share of university graduates vote significantly more secular and less Islamist than constituencies with a lower share of university graduates. Furthermore, the rate of illiteracy of a constituency is significantly correlated with a higher share of Islamist voting. This is not particularly surprising due to the information dissemination and propaganda in favour of political Islam in mosques, which are a major source of information for less educated voters. However, what is surprising is the fact that, when controlling for education, poor constituencies do not vote more strongly Islamist. This result, thus, suggests that the choice of voting for an Islamist party has been more strongly driven by religious outreach and not by social outreach. Our findings, which are based on a multivariate analysis, disentangle those of Erle et al. (2011) who conclude - based on a cluster analysis of voting intentions - that poor constituencies

\footnotetext{
${ }^{32}$ We have not used this specification while estimating the general model in the first place; due to the existence of multicollinearity when adding the distance variable to our general model. This is particularly due to the strong centrist nature of the Egyptian state, where the political periphery also coincides with being the social periphery.
} 
show a higher support for Islamist parties while rich constituencies vote more in favour of secular parties.

With the first elections after a youth-led revolution as the subject of our analysis, it is interesting to note that younger constituencies have not chosen to express their disgruntlement with the previous regime by voting more strongly for Islamist parties, but that a larger share of the population between the ages of 15 and 45 has correlated with a higher share of secular voting at a high significance level. Our analysis further reveals that higher degrees of private sector employment show lower support for Islamist parties; while higher public sector employment seems to be highly significant and correlated with higher degrees of Islamist and lower degrees of secular voting. These findings are in line with Fidrmuc's (2000) prospective voting argument, as voters seem to favour parties that more strongly represent their interests.

Another interesting aspect of our analysis has been the identification of the implications of the sequential voting procedure that was implemented in Egypt's first post-revolutionary elections. Islamist parties, and particularly the Muslim Brotherhood, next to engaging in strong social outreach programmes have a long history of political opposition and a high degree of organization. Secular parties, on the other hand, are quite weak in those dimensions. Particularly, in light of the transitional phase of the country and the according low level of knowledge about the voters' preferences before the beginning of the elections on the one hand and in the context of the higher organizational skills of the Islamist parties on the other hand, it is highly interesting how the announcement of earlier stage results has affected voting outcomes in later stages. In this case, our regressions have shown that the sequential voting framework has actually worked against the Islamists parties, with support for Islamist parties significantly declining in the last stage of the vote. This finding is particularly interesting given the special task of the elected parliament in nominating the committee who will draft the new constitution. Voters of the third and final election stage might have opted to vote less in favour of the winner of the previous stages in order to see more ideological diversity in the parliament. However, we do not find the increase in support for the group of secular parties in stage three to be statistically significant. The decline in support for the Islamist parties rather goes in hand with a greater diversification of votes. 


\section{Appendix}

Table A.1: Summary statistics of explanatory variables ( $n=46$ constituencies)

\begin{tabular}{|c|c|c|c|c|c|c|c|}
\hline Variable & Obs. & Mean & $\begin{array}{l}\text { Std. } \\
\text { Dev. }\end{array}$ & Min. & Max. & $\begin{array}{c}\text { Correlation } \\
\text { Islamist } \\
\text { voting }\end{array}$ & $\begin{array}{c}\text { Correlation } \\
\text { secular } \\
\text { voting }\end{array}$ \\
\hline University education & 46 & 9.14 & 4.77 & 2.83 & 25.00 & $-0.40 * * *$ & $0.45 * * *$ \\
\hline Illiteracy rate & 46 & 29.11 & 8.79 & 12.86 & 44.94 & $0.36^{* *}$ & $-0.27 *$ \\
\hline \multicolumn{8}{|l|}{ No public sanitation } \\
\hline (poverty proxy) & 46 & 57.42 & 29.54 & 1.42 & 96.90 & 0.10 & -0.11 \\
\hline Women in labour force & 46 & 17.64 & 4.56 & 9.38 & 26.63 & -0.16 & $0.35^{* *}$ \\
\hline Age group 15-45 & 46 & 50.19 & 3.72 & 45.73 & 68.95 & $-0.41 * * *$ & $0.44 * * *$ \\
\hline Age group 45-60 & 46 & 12.13 & 1.84 & 9.34 & 17.18 & -0.11 & 0.15 \\
\hline Age group above 60 & 46 & 6.02 & 1.41 & 2.68 & 11.49 & -0.11 & 0.15 \\
\hline Unemployment rate & 46 & 9.47 & 2.92 & 4.85 & 18.74 & -0.14 & 0.03 \\
\hline Public employment & 46 & 11.44 & 4.67 & 3.82 & 30.75 & 0.05 & -0.10 \\
\hline Dummy: 2. election stage & 46 & 0.33 & 0.47 & 0 & 1 & 0.19 & -0.07 \\
\hline Dummy: 3. election stage & 46 & 0.33 & 0.47 & 0 & 1 & -0.06 & -0.12 \\
\hline
\end{tabular}

Notes: (i) $*, *, * * *$ indicate significance at a $10 \%, 5 \%$, and $1 \%$ level, respectively.

Table A.2: Descriptives by stage

\begin{tabular}{lccc}
\hline Variables* & Stage 1 & Stage 2 & Stage 3 \\
\hline University education & 11.32 & 7.72 & 8.24 \\
Illiteracy rate & 27.40 & 31.16 & 28.89 \\
No public sanitation & 46.59 & 66.39 & 59.98 \\
Women in labour force & 18.08 & 17.85 & 16.97 \\
Public employment & 10.27 & 11.25 & 12.88 \\
Unemployment rate & 9.68 & 9.87 & 8.85 \\
Age group 15-45 & 50.47 & 49.62 & 50.47 \\
Age group 45-60 & 12.96 & 11.75 & 11.63 \\
Age group above 60 & 6.71 & 5.74 & 5.57 \\
\hline Distance to Cairo & 218.46 & 226.77 & 275.71 \\
Number of constituencies & 16 & 15 & 15 \\
\hline
\end{tabular}

*Calculated means by stage. 
Table A.3: Summary statistics of parties' proportional representation

\begin{tabular}{|c|c|c|c|}
\hline English Name of Party (translation) & $\begin{array}{c}\text { No. of } \\
\text { Constituencies }\end{array}$ & $\begin{array}{c}\text { Average } \\
\text { representation } \\
\text { (in \%) }\end{array}$ & $\begin{array}{l}\text { Arabic Name of } \\
\text { Party }\end{array}$ \\
\hline \multicolumn{4}{|c|}{ Islamist Parties } \\
\hline Freedom and Justice Party & 46 & 32.64 & الحرية و العدالة \\
\hline Nour Party & 44 & 28.19 & 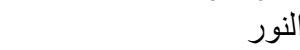 \\
\hline \multicolumn{4}{|c|}{ Secular Parties } \\
\hline Democratic Front Party & 12 & 0.72 & الجبهة الديمقر اطية \\
\hline Egyptian Block & 42 & 9.04 & الكتلة المصرية \\
\hline Ghad Party & 15 & 1.05 & الغد \\
\hline New Wafd Party & 45 & 8.97 & الوفد \\
\hline Reform and Development Party & 43 & 3.06 & الاصلاح و التنمية \\
\hline \multicolumn{4}{|c|}{ Other Parties } \\
\hline Adl Party (Justice Party) & 20 & 1.45 & العدل \\
\hline Arab Party for Justice and Equality & 7 & 1.71 & العربي للعدل و المساوة \\
\hline Awareness Party & 2 & 0.23 & 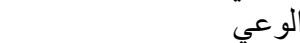 \\
\hline Conservative Party & 29 & 1.5 & المحافَّين \\
\hline Democratic Peace & 23 & 1.87 & 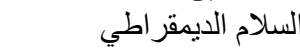 \\
\hline Democratic People Party & 1 & 0.25 & 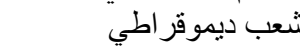 \\
\hline Egypt of the Revolution Party & 6 & 1.26 & مصر الثورة - مص \\
\hline Egyptian Arab Union Party & 14 & 0.96 & ل الاتحاد المصري العربي \\
\hline Egyptian Citizen Party & 19 & 2.56 & لـواطن المصري الي \\
\hline $\begin{array}{l}\text { Egyptian Development and Justice } \\
\text { Party }\end{array}$ & 2 & 0.91 & التنمية و العدالة المصري \\
\hline Egyptian Liberation Party & 2 & 0.54 & التحرير المصري \\
\hline Egyptian Revolution Party & 12 & 0.73 & الثورة المصرية \\
\hline Free Constitutional Socialists & 2 & 0.36 & الدستوري الإجتماعي الحر \\
\hline Free Socialists & 1 & 0.24 & لاحر ار ألاشتر اكيين \\
\hline Freedom Party & 33 & 3.47 & الحرية \\
\hline Guardians of the Revolution Party & 4 & 1.84 & حر اس الثورة \\
\hline Human Rights and Citizenship Party & 1 & 0.44 & حقوق الانسان و المو اطنة \\
\hline Modern Egypt Party & 16 & 0.73 & مصر الحديثة \\
\hline Nasserist Party & 14 & 1.9 & العربي الناصري \\
\hline National Egypt Party & 19 & 3.68 & مصر "القومي \\
\hline New Independents Party & 10 & 1.62 & المستقلين الجدد \\
\hline Omma Party (Nation Party) & 1 & 1.24 & 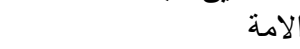 \\
\hline Reform and Development Party & 43 & 3.06 & لاصلاح و التنمية \\
\hline Revolution Continues Alliance & 31 & 3.64 & الثورة المستمرة \\
\hline Socialist Party & 2 & 3.27 & لاشتر اكيين \\
\hline Socialist Peace Party & 5 & 0.61 & السلام الاجتماعي \\
\hline Union Party & 14 & 2.38 & 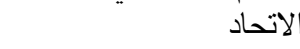 \\
\hline Voice of Egypt Party & 1 & 0.85 & صوت مصر \\
\hline Wasat Party (Centrist Party) & 44 & 3.9 & الوسط الجديد \\
\hline
\end{tabular}


Table A.4: Determinants of Islamist and secular votes - SUR results

\begin{tabular}{|c|c|c|c|c|}
\hline \multirow{2}{*}{$\begin{array}{l}\text { Model } \\
\text { Variables } \\
\end{array}$} & \multicolumn{2}{|c|}{ Islamist voting: SUR } & \multicolumn{2}{|c|}{ Secular voting: SUR } \\
\hline & Coefficients & $\mathrm{SE}$ & Coefficients & SE \\
\hline \multicolumn{5}{|l|}{ a) Socio-economic background } \\
\hline University education & $-1.833 * * *$ & 0.584 & $1.385 * * *$ & 0.456 \\
\hline Illiteracy rate & $0.642 *$ & 0.337 & -0.025 & 0.263 \\
\hline No access to public sanitation & $-0.299 * * *$ & 0.078 & $0.229 * * *$ & 0.061 \\
\hline Women in labour force & 0.386 & 0.362 & 0.445 & 0.282 \\
\hline Age group $15-45$ & -0.583 & 0.489 & $0.949 * * *$ & 0.366 \\
\hline Age group 45-60 & 1.653 & 1.360 & -0.210 & 1.062 \\
\hline Age group above 60 & $-3.682 * * *$ & 1.422 & $2.086^{*}$ & 1.110 \\
\hline \multicolumn{5}{|l|}{$\begin{array}{l}\text { b) Economic and employment } \\
\text { structure }\end{array}$} \\
\hline Unemployment rate & -0.093 & 0.466 & -0.109 & 0.364 \\
\hline Public employment & 0.586 & 0.373 & $-0.545^{*}$ & 0.291 \\
\hline \multicolumn{5}{|c|}{ c) Electoral institutional framework } \\
\hline Dummy: $2^{\text {nd }}$ election stage & -0.922 & 2.821 & 0.718 & 2.202 \\
\hline Dummy: $3^{\text {rd }}$ election stage & $-4.696^{*}$ & 2.821 & 1.454 & 2.202 \\
\hline Constant & $97.786 * * *$ & 36.833 & $-63.483 *$ & 28.792 \\
\hline (1) No. of observations & 46 & & 46 & \\
\hline (2) SE of regression & 6.778 & & 5.291 & \\
\hline (3) $\mathrm{R}^{2}$ & 0.561 & & 0.600 & \\
\hline (4) Test of joint significance & $\operatorname{Chi} 2(11)=58$ & $2 * * *$ & $\operatorname{Chi} 2(11)=6$ & $2 * * *$ \\
\hline
\end{tabular}


Table A.5: Determinants of voting for Islamist parties: Robustness analysis

\begin{tabular}{|c|c|c|c|c|c|c|c|c|c|c|}
\hline Model & \multicolumn{2}{|c|}{ Specification (1) } & \multicolumn{2}{|c|}{ Specification (2) } & \multicolumn{2}{|c|}{ Specification (3) } & \multicolumn{2}{|c|}{ Specification (4) } & \multicolumn{2}{|c|}{ Specification (5) } \\
\hline Variables & Coefficients & SE & Coefficients & SE & Coefficients & SE & Coefficients & SE & Coefficients & SE \\
\hline University education & $-1.481^{* *}$ & 0.592 & $-1.601 * * *$ & 0.567 & $-1.120 * *$ & 0.565 & $-1.888 * *$ & 0.871 & $-1.886 * * *$ & 0.534 \\
\hline Illiteracy rate & $0.656 * *$ & 0.287 & $0.853 * * *$ & 0.307 & & & 0.638 & 0.391 & 0.466 & 0.350 \\
\hline No educational degree & & & & & $0.868 * * *$ & 0.251 & & & & \\
\hline No public sanitation & $-0.339 * * *$ & 0.082 & $-0.345 * * *$ & 0.079 & $-0.321 * * *$ & 0.073 & $-0.284 * * *$ & 0.101 & $-0.278 * * *$ & 0.085 \\
\hline Illiteracy*No Public sanitation & & & -0.001 & 0.006 & & & & & & \\
\hline Age group above 60 & $-2,753 * *$ & 1.193 & $-1.637 *$ & 0.098 & $-1.707 *$ & 0.938 & -2.535 & 1.811 & $-1.593 *$ & 0.948 \\
\hline Public employment & & & $0.914 * * *$ & 0.324 & $0.934 * * *$ & 0.305 & $0.978 * *$ & 0.372 & $0.649 *$ & 0.348 \\
\hline Private employment & $-0.410 *$ & 0.235 & & & & & & & & \\
\hline Dummy: $3^{\text {rd }}$ election stage & -3.926 & 2.692 & $-4.889 *$ & 2.626 & $-4.539 *$ & 2.499 & $-5.046^{*}$ & 3.009 & $-4.337 *$ & 2.534 \\
\hline Distance to Cairo & & & & & & & & & $-0.012 *$ & 0.007 \\
\hline Constant & $105.986^{* * *}$ & 14.176 & $72.754 * * *$ & 15.569 & $56.647 * * *$ & 17.163 & $81.814 * * *$ & 22.510 & $88.024 * * *$ & 16.997 \\
\hline (1) No. of obs & 46 & & 46 & & 46 & & 30 & & 46 & \\
\hline (2) $\mathrm{R}^{2}$ & 0.468 & & 0.526 & & 0.555 & & 0.447 & & 0.559 & \\
\hline (3) Adjusted $R^{2}$ & 0.386 & & 0.438 & & 0.486 & & 0.303 & & 0.478 & \\
\hline (4) Joint significance & $F(6,39)=5.7$ & $2 * * *$ & $F(7,38)=6.0$ & $2 * * *$ & $\mathrm{~F}(6,39)=8.1$ & $0 * * *$ & $\mathrm{~F}(6,23)=3$. & $0 * *$ & $F(7,38)=6.9$ & $0 * * *$ \\
\hline
\end{tabular}

Notes: (i) Results are based on an OLS estimation. (ii) *, *,*** indicate significance at a $10 \%, 5 \%$, and $1 \%$ level, respectively. (iii) Dependent variable is the share of votes accrued to Islamist parties. 
Table A.6: Determinants of voting for secular parties: Robustness analysis

\begin{tabular}{|c|c|c|c|c|c|c|c|c|c|c|}
\hline Model & Specificatio & n (1) & Specificatic & $n(2)$ & Specificati & n(3) & Specificatio & on (4) & Specificati & on (5) \\
\hline Variables & Coefficients & SE & Coefficients & SE & Coefficients & SE & Coefficients & SE & Coefficients & SE \\
\hline University education & $1.474 * * *$ & 0.447 & $1.293 * *$ & 0.483 & $1.289 * *$ & 0.497 & 1.179 & 0.745 & $1.367 * * *$ & 0.432 \\
\hline Illiteracy rate & & & -0.014 & 0.251 & & & & & & \\
\hline No educational degree & & & & & -0.063 & 0.234 & & & & \\
\hline No public sanitation & $0.243 * * *$ & 0.059 & $0.236^{* * *}$ & 0.061 & $0.235^{* * *}$ & 0.059 & $0.211 * * *$ & 0.071 & $0.224 * * *$ & 0.059 \\
\hline Illiteracy*No Public sanitation & & & 0.003 & 0.005 & & & & & & \\
\hline Women in labour force & 0.150 & 0.270 & 0.381 & 0.331 & 0.480 & 0.297 & 0.172 & 0.348 & 0.461 & 0.294 \\
\hline Age group 15-45 & $0.736^{*}$ & 0.422 & $1.061 * *$ & 0.418 & $0.908 * *$ & 0.414 & $1.143 * *$ & 0.521 & $0.905 * *$ & 0.368 \\
\hline Age group above 60 & $2.436^{* * *}$ & 0.903 & $1.993 * *$ & 0.966 & $1.798 * *$ & 0.925 & 0.865 & 1.668 & $1.814^{*}$ & 0.916 \\
\hline Public employment & & & -0.467 & 0.301 & $-0.570 * *$ & 0.291 & -0.287 & 0.295 & $-0.514^{* *}$ & 0.245 \\
\hline Private employment & 0.262 & 0.187 & & & & & & & & \\
\hline Dummy: $3^{\text {rd }}$ election stage & 0.564 & 2.017 & 1.197 & 2.026 & 1.121 & 2.004 & -0.102 & 2.303 & 1.013 & 2.001 \\
\hline Distance to Cairo & & & & & & & & & 0.003 & 0.005 \\
\hline Constant & -69.231 & 22.227 & $-72.034 * *$ & 28.516 & $-60.848 * *$ & 32.085 & $-64.964 * *$ & 30.390 & $-64.429 * * *$ & 22.003 \\
\hline (1) No. of observations & 46 & & 46 & & 46 & & 30 & & 46 & \\
\hline (2) $\mathrm{R}^{2}$ & 0.570 & & 0.602 & & 0.598 & & 0.574 & & 0.601 & \\
\hline (3) Adjusted $R^{2}$ & 0.490 & & 0.502 & & 0.512 & & 0.439 & & 0.515 & \\
\hline (4) Joint significance & $\mathrm{F}(7,38)=7.1$ & $8 * * *$ & $\mathrm{~F}(9,36)=6.0$ & $5 * * *$ & $\mathrm{~F}(8,37)=6$ & $9 * * *$ & $\mathrm{~F}(7,22)=4.2$ & $24 * *$ & $\mathrm{~F}(8,37)=6.9$ & $8 * * *$ \\
\hline
\end{tabular}




\section{References}

Akarca, A. and Tansel, A. (2006). Economic performance and political outcomes: An analysis of the Turkish parliamentary and local election results between 1950 and 2004. Public Choice 129(1), 77-105.

April $6^{\text {th }}$ Youth Movement, Awareness campaign against regime remnants. www.emsekflol.com. Accessed on 01.08.2012

Battaglini, M. (2005). Sequential voting with abstention. Games and Economic Behavior 51, 445-463.

Baslevent, C., Kirmanoglu, H. and Senatalar, B. (2005). Empirical investigation of party preferences and economic voting in Turkey. European Journal of Political Research 44, 547562.

Breusch, T. S. and Pagan, A. R. (1979). A Simple test for heteroscedasticity and random coefficient variation. Econometrica 47 (5), 1287-1294.

Brown, G. (2011). Salafis and Sufis in Egypt. The Carnegie Papers December 2011.

Brown, K. M. and Zech, C. E. (1973). Welfare effects of announcing election forecasts, Public Choice 14, 117-123.

Carnegie Endowment for International Peace. (2012). Guide to Egypt's transition. http://egyptelections.carnegieendowment.org/. Accessed on 30.05.2012.

Carter Center Election Monitoring Mission (2012). Preliminary Report an all three phases of the people's assembly elections. www.cartercenter.org. Accessed on 29.07.2012.

Central Agency for Public Mobilisation and Statistics (CAPMAS) (2006). CAPMAS Population and Housing Census data.

Dekel, E. and Piccione, M. (2000). Sequential voting procedures in symmetric binary elections. Journal of Political Economy 108, 34-55.

Egyptian Election Authority (2011). People's assembly election results. www.elections2011.com.eg. Accessed on 19.04.2012.

Erle, J., Wichmann, J. M. and Kjaerum, A. (2011). Egypt electoral constituencies. Socioeconomic classification of Egypt's electoral constituencies, Report Danish-Egyptian Dialogue Institute.

Fidrmuc, J. (2000). Political support for reforms: Economics of voting in transition countries, European Economic Review 44(8), 1491-1513.

Fleitas, D. W. (1971). Bandwagon and Underdog Effects in Minimal-Information Elections, American Political Science Review 65, 434-438. 
Gärtner, M. (1976). Endogenous bandwagon and underdog effects in a rational choice model, Public Choice 25(1), 83-89.

Genç, H., Şahin . H., Bekmez S. (2005). Homoeconomical behavior of Turkish Electorate, Southwestern Journal of Economics 7, 1-24.

Hendry, D. F. (2001). Econometrics: Alchemy or Science? Oxford University Press, Oxford.

International Foundation for Electoral Systems (2012). IFES Egypt country briefing. http://www.ifes.org/countries/Egypt.aspx. Accessed on 01.06.2012.

Lewis-Beck, M. (1988). Economics and elections: The major western democracies. University of Michigan Press, Ann Arbor.

Lewis-Beck, M. S. and Stegmaier, M. (2000). Economic determinants of electoral outcomes. Annual Review of Political Science 3, 183-219.

Morton, R. amd Williams, K. (1999). Information asymmetries and simultaneous vs. sequential voting. American Political Science Review 93, 51-67.

Nannestad, P. and Paldam, M. (1994). The VP-function: A survey of the literature on vote and popularity functions after 25 years. Public Choice 79, 213-245.

Norris, P. (2004). Electoral Engineering: Voting Rules and Political. Cambridge University Press, Cambridge.

Palfrey, T. (2009). Laboratory experiments in political economy. Annual Review of Political Science 12, 379-388.

Pew Global Attitudes Project. (2012). Egyptians remain optimistic, embrace democracy and religion in political life. www.pewresearch.org. Accessed on 01.07.2012.

Potrafke, N. (2011). Islam and democracy, Public Choice, 151(1-2), 185-192.

Powell, G. B. and Whitten, G. D. (1993). A cross-national analysis of economic voting: Taking account of the political context. American Journal of Political Science 37, 391-414.

Rahman, M. A. (2011). Effacing Women in Salafi Campaign Bid. Alakhbar English (15 November 2011). http://english.al-akhbar.com/node/1505. Accessed on 02.08.2012.

Ramsey, J. B. (1969), Tests of specification errors in classical linear regression analysis, Journal of Royal Statistical Society, Series B, 31 (2), 350-371.

Rowley, C. K. and Smith, N. (2009). Islam's democracy paradox: Muslims claim to like democracy, so why do they have so little? Public Choice, 139(3-4), 273-299.

Said, M. (2012). Compensating Differentials and the Value of Job Security: Evidence from the Egyptian Public Sector, International Journal of Economics and Finance 4(1), 56-69. 
Schneider, F. (2002). Size and measurement of the informal economy in 110 economies around the World, mimeo.

Shapiro, S. S. and Wilk, M.B. (1965). An analysis of variance test for normality (for complete samples), Biometrika 52 (3-4), 591-611.

Simon, H. A. (1954). Bandwagon and underdog effects and the possibility of elections predictions. Public Opinion Quarterly 18(3), 245-53.

Swank, O. H. and Eisinga, R. (1999). Economic outcomes and voting behaviour in a multiparty system: An application to the Netherlands, Public Choice 101(3-4), 195-213.

Wickham, C. R. (2002). Mobilizing Islam: Religion, activism, and political change in Egypt. Columbia University Press, New York.

Wilcoxon, Frank (1945). "Individual comparisons by ranking methods". Biometrics Bulletin 1 (6): 80-83. 